\title{
Pengaruh Terpaan Media Line Webtoon “Wonderwall” terhadap Opini Pembaca Mengenai Isu Kesehatan Mental
}

\author{
Putri Oktavia Haliem, Farid, Budi Utami \\ putrihaliem@gmail.com,farid@fikom.untar.ac.id,amibudiutami@gmail.com
}

Fakultas Ilmu Komunikasi, Universitas Tarumanagara.

\begin{abstract}
Naver Webtoon is online media comic, was founded by Kim Jun Koo, was established on June 23, 2004 in Korea by Naver (one of the largest internet companies in Korea), launched globally as Line Webtoon in 2014, and has 17 million users per month. Line Webtoon also provides Webtoon in various languages, one of them is Indonesian (Bahasa). One of the well-known Webtoon titles in Indonesian is 'Wonderwall' which was the object of this research. Line Webtoon 'Wonderwall' is a romantic genre and tells the story of a girl named Jessy, and her school life, a love story with a boy who is feared by student in the school and the story that leads to mental health issues such as trauma, hand-wrenching, bullying mental, etc. . The purpose of this study is to see how much the influence of Media Exposure of Line Webtoon's 'Wonderwall' on readers' opinions on mental health issues. this study uses media exposure, and opinion. The researcher used a quantitative method with an associative type of research. This will be tested using validity, reliability, normality, correlation coefficient, determination coefficient, simple linear regression, and t test. It can be concluded, the influence of Media Exposure of Line Webtoon's 'Wonderwall' on readers' opinions about mental health issues. which means there is an influence from Media Exposure of Line Webtoon's 'Wonderwall' on Reader Opinions on mental health issues. . This can be seen from the results of the t test which shows a significant number (sig.) 0,000.
\end{abstract}

Keyword: Comic Online Wonderwall, Media Exposure, Opinions, Mental Health Issues.

\begin{abstract}
Abstrak
Naver Webtoon adalah sebuah media komik online yang didirikan oleh Kim Jun Koo pada tanggal 23 Juni 2004 di Korea. Diluncurkan secara global sebagai Line Webtoon pada tahun 2014, dan memiliki 17 Juta pengguna per bulannya. Line Webtoon juga menyediakan Webtoon dalam berbagai Bahasa, salah satunya adalah Indonesia. Beberapa judul Webtoon yang tersedia dalam Bahasa Indonesia yang cukup terkenal adalah Line Webtoon 'Wonderwall' yang menjadi objek dari penelitian ini. Line Webtoon 'Wonderwall' sendiri bergenre romantis dan menceritakan tentang kisah seorang gadis bernama Jessy, dan kehidupan sekolahnya, kisah asmara dengan anak laki-laki yang ditakuti oleh anak sekolah yang mengandung konten yang mengarah ke isu kesehatan mental seperti trauma, suka menyayat tangan, dll. Tujuan dari penelitian ini adalah untuk melihat seberapa jauh pengaruh terpaan media Line Webtoon "Wonderwall" terhadap opini pembaca mengenai isu kesehatan mental. Penelitian ini menggunakan dasar teori terpaan media, dan opini. Peneliti menggunakan metode kuantitatif dengan jenis penelitian asosiatif. Hal ini akan diuji dengan menggunakan uji validitas, realibilitas, normalitas, koefisien korelasi, koefisien determinasi, regresi linear sederhana, dan uji t. Dapat disimpulkan, bahwa terdapat pengaruh terpaan media Line Webtoon "Wonderwall" terhadap opini pembaca mengenai isu kesehatan mental. Hal ini dapat dilihat dari hasil uji t yang menunjukan angka signifikan (sig.) 0.000.
\end{abstract}

Kata Kunci: Komik Online Wonderwall, Terpaan media, Opini, Kesehatan Mental 


\section{Pendahuluan}

Ketika seseorang mendengarkan siaran radio, menonton televisi, atau membaca surat kabar, dll. Sebenarnya ia sedang berhadapan dengan atau terterpa media, dimana pesan media itu secara langsung atau tidak langsung tengah memengaruhinya.

Dengan perkembang teknologi yang pesat, berbagai jenis media ikut berkembang salah satunya adalah media online. Data hasil survei Asosiasi Penyelenggara Jasa Internet Indonesia (APJII) tahun 2017 mengatakan bahwa pengguna internet saat ini masih didomisili oleh kisaran umur 19 tahun hingga 34 tahun. Salah satu media online yang kini berkembang dan banyak digemari oleh kalangan remaja-dewasa adalah Komik Digital.

Komik yang biasanya harus dibeli di toko buku, dan masih berbentuk buku cetak, kini tersedia dalam bentuk digital yang sering disebut komik digital. Platform yang menyediakan komik digital sudah cukup banyak. Line Webtoon adalah salah satu platform yang paling di gemari dengan jumlah download hingga 10 Juta download, menurut data di Google Play Store.

Komik di Line Webtoon sangat beragam. Mulai dari sebuah kisah romantis hingga sebuah kisah yang juga membahas isu-isu yang marak di antara masyarakat, seperti Line Webtoon I Am Gangnam Beauty yang membahas tentang adanya kesenjangan sosial bagi para wanita yang dianggap tidak cantik dan ada juga Wonderwall yang berceritakan tentang kondisi psikologis seorang korban pemerkosaan, Line Webtoon 'Wonderwall' ini sendiri menceritakan tentang kisah seorang gadis bernama jessy, dan kehiudap sekolahnya, berawal dari kisah asmara anak sekolah biasa ternyata terungkap bahwa jessy adalah salah satu korban pemerkosa dari anak kepala sekolah si sekolahnya, mengalami banyak trauma jessy mulai menunjukan adanya gejala-gejala gangguan mental pada sahabatnya seperti menyayat tangannya, dan mengatakan ingin mati saja.

\section{Gambar 1}

Tampilan Webtoon "Wonderwall"

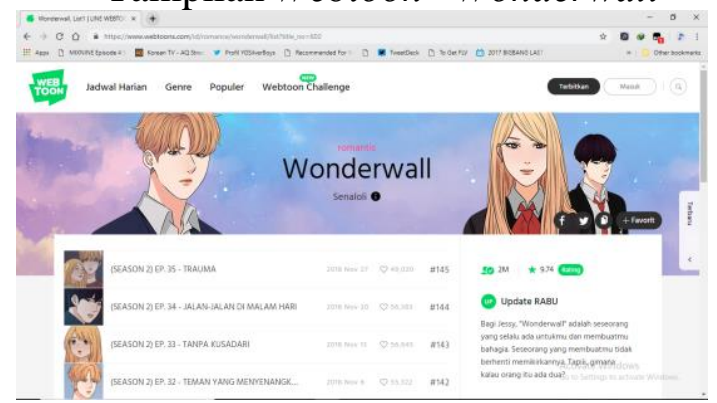

Sumber : situs http://Webtoon.com/id/ romance/wonderwall/list?title_no=602

Hingga kini, berdasarkan data yang tertera di aplikasi Line Webtoon pengikut Line Webtoon 'Wonderwall' pertanggal 1 Oktober 2018 mencapai 1.9 Juta pengguna dengan rating 9.74.

Fakta menurut data kementrian kesehatan 14 juta orang di Indonesia yang berumur diatas 15 tahun mengalami gejala depresi dan gangguan jiwa. gangguan jiwa sendiri berpengaruh terhadap produktivitas kerja yang menurun hingga menyebabkan kerugian secara ekonomi. Masyarakat indonesia sendiri masih banyak 
yang menilai orang yang memiliki masalah dengan mental mereka adalah "orang gila".

Komik digital sebagai salah satu bentuk media baru di indonesia, mungkin dapat memberi pengaruh tersendiri terhadap opini pembaca remaja - dewasa kisaran umur 19 - 34Thn, sesuai dengan kalangan pengguna yang mendomisili internet di indonesia. Penulis sendiri ingin membuktikan dan melihat sendiri dengan meneliti hal ini, apakah terpaan media komik digital Line Webtoon "Wonderwall" dapat memberi pengaruh terhadap opini pembaca mengenai isu kesehatan mental di indonesia. Oleh karena itu sesuai pembahasan diatas penulis melakukan penelitian dengan judul: "Pengaruh terpaan media Line Webtoon "Wonderwall" Terhadap opini Pembaca Mengenai Isu Kesehatan Mental"

Dalam Penelitian ini, penulis menggunakan teori, sebagai berikut:

a. Terpaan Media

Terpaan merupakan intensitas keadaan khalayak dimana terkena pesanpesan yang disebarkan oleh suatu media. Menurut Ardianto (2014: 168), terpaan bisa diartikan sebagai kegiatan mendengar, melihat, dan membaca pesan-pesan media ataupun memiliki pengalaman dan perhatian terhadap pesan tersebut yang dapat terjadi pada seseorang atau suatu kelompok.

Menurut Rosengren dalam Rizki dan Pengestuti (2017), terpaan media dapat diukur dengan dimensi sebagai berikut:

1. Frekuensi, yaitu rutinitas atau beberapa kali seseorang menggunakan media dan mengkonsumsi isi pesan dari media.

2. Durasi, yaitu berapa lama seseorang menggunakan media dan mengkonsumsi isi pesan dari media

3. Atensi, yaitu perhatian yang diberikan seseorang dalam menggunakan media dan mengkonsumsi isi pesan dari media.

b. Opini

Menurut Sunarjo (1997:85), opini adalah sebuah jawaban terbuka pada suatu persoalan atau suatu isu yang jawabannya diajukan secara tulisan ataupun lisan. Opini juga dapat dianggap sebagai jawaban lisan seseorang yang memberi respon atau tanggapan kepada ransangan dimana suatu keadaan atau suatu kondisi yang pada umumnya diajukan suatu pertanyaan.

Menurut William dan Cleve (1994, hal.14), setiap opini memiliki tiga komponen yaitu:

a. Kepercayaan

Kepercayaan adalah suatu keadaan yang mengacu pada sesuatu yang diterima khalayak, benar atau tidak berdasarkan pengalaman masa lalu, pengetahuan dan informasi sekarang dan persepsi yang berkesinambungan.

b. Nilai

Nilai adalah suatu keadaan suka atau tidak suka, cinta atau benci, hasrat atau ketakutan, bagaimana orang menilai sesuatu apakah kuat, lemah, netral.

c. Pengharapan

Pengharapan mengandung citra seseorang tentang apa keadaannya setelah tindakan. Pengharapan, ditentukan dari pertimbangan terhadap sesuatu yang terjadi pada masa lalu, keadaan sekarang, dan sesuatu yang kira-kira akan terjadi jika dilakukan perbuatan tertentu (Karra Sugianto, 2017) 


\section{Metode Penelitian}

Penulis menggunakan metode penelitian kuantitatif dan jenis penelitian yang digunakan adalah asosiatif, dimana menurut Syofian Siregar (2015:7) merupakan penelitian yang bertujuan untuk mengetahui hubungan antara dua variabel atau lebih dengan. Dengan penelitian ini maka akan dapat dibangun suatu teori yang dapat berfungsi untuk menjelaskan, meramalkan dan mengontrol suatu teori yang didapat berfungsi untuk menjelaskan, meramalkan dan mengontrol suatu gejala.

a. Populasi

Populasi dalam penelitian ini adalah pembaca dari Line Webtoon 'Wonderwall' yang berkisaran umur 18 hingga 35 tahun. Berdasarkan data yang tertera pada aplikasi google play, ada sekitar 10jt user yang telah mendownload aplikasi Line Webtoon dan sekiranya ada sekitar 1,9jt pengikut (per tanggal 5 Oktober 2018) atau pembaca untuk Line Webtoon "Wonderwall” yang menjadi populasi dalam penelitian ini.

b. Sampel

Penelitian ini menggunakan sampling incidental yang di jelaskan oleh sugiyono (2011:124) adalah teknik penentuan sampel berdasarkan kebetulan, siapa saja yang bertemu dengan peneliti secara kebetulan dapat digunakan sebagai sampel bila dipandang bahwa orang tersebut cocok dengan kriteria dari penelitian ini.

Penulis menggunakan rumus slovin (Umar, 2008:78) untuk menentukan banyak sampel yang akan digunakan dalam penelitian ini:

Keterangan:

$$
n: \frac{N}{\left(1+N \cdot e^{2}\right)}
$$

$$
\begin{aligned}
& \mathrm{n}=\text { sampel } \\
& \mathrm{N}=\text { populasi } \\
& \mathrm{E}=\text { persen kelonggaran ketidak-telitian Dalam }
\end{aligned}
$$

penelitian ini nilai kritisnya sebesar $10 \%$

Berdasarkan data yang diperoleh dari Aplikasi Line Webtoon, jumlah pengikut atau perkiraan pembaca Line Webtoon "Wonderwall" saat ini adalah 1,9 juta user. Jika dimasukan ke dalam rumus Slovin, maka hasil sampel yang didapat sebagai berikut:

$$
\begin{gathered}
n: \frac{1.900 .000}{\left(1+1.900 .000 \cdot\left(0.1^{2}\right)\right.} \\
n: \frac{1.900 .000}{19.001} \\
n: \frac{1.900 .000}{19.001} \\
n: 99.99 \quad n: 100
\end{gathered}
$$

Jadi dalam penelitian ini akan mengambil sampel sebanyak 100 responden. 


\section{Hasil Temuan dan Diskusi}

Tabel 1

Hasil Uji Test of Significant ( Uji t ) Variabel Terpaan Media ( X )

\begin{tabular}{cccc}
\hline & \multicolumn{3}{c}{ Terpaan Media terhadap Opini } \\
\hline A & 3.419 & T & 15.240 \\
B & $\mathbf{0 . 2 2 6}$ & Sig & 0.000 \\
\hline
\end{tabular}

Sumber : Hasil kuesioner yang diolah dengan SPSS

Tabel 2

Hasil Koefisien Korelasi (R) Variabel Terpaan Media (X)

\begin{tabular}{ccc}
\hline & $\mathbf{R}$ & $\mathbf{R}^{2}$ \\
\hline $\begin{array}{c}\text { Terpaan Media } \\
\text { terhadap Opini }\end{array}$ & $\mathbf{0 . 4 5 7}$ & $\mathbf{0 . 1 3 5}$ \\
\hline
\end{tabular}

Sumber : Hasil kuesioner yang diolah dengan SPSS

a. Pada tabel 2 diperoleh hasil kesimpulan bahwa nilai koefisien korelasi ( $\mathrm{R}$ ) untuk Variabel Terpaan Media (X) adalah sebesar 0.457. Artinya bahwa hubungan antara X dan Y dikatakan sedang karena berada dalam interval 0.4 -0.59 .

b. Berdasarkan tabel 2, diperoleh hasil koefisien determinasi dengan menggunakan nilai $\mathrm{R}$ Square $\left(\mathrm{R}^{2}\right)$ yaitu sebesar 0.135 yang berarti bahwa kemampuan Variabel Terpaan Media (X) dalam menjelaskan variabel dependen Opini (Y) adalah sebesar 13,5\%, sedangkan sisanya adalah 86,5\% dijelaskan oleh faktor - faktor lain yang tidak dijelaskan dalam model regresi penelitian ini.

c. Persamaan regresi linear sederhana pada tabel 4.25 untuk variabel Terpaan Media (X) terhadap Opini (Y) yang didapatkan dalam penelitian ini adalah sebagai berikut:

$$
Y=3.419+0.226 X
$$

Nilai 3.419 mengandung pengertian bahwa perpotongan garis pada sumbu variabel dependen Opini (Y) terletak pada angka 3.419. Nilai ini tidak tergantung pada nilai variabel Terpaan Media (X). Maka nilai 3.419 merupakan nilai konstan yang menunjukan bahwa jika ada kenaikan Terpaan media, maka nilai Opini mencapai 3.419.

Sedangkan 0.226 merupakan koefisien regresi yang menunjukan bahwa setiap ada penambahan satu nilai atau angka untuk Terpaan Media, maka akan ada kenaikan Opini sebesar 0.226. Dengan begitu, semakin besar nilai X akan mempengaruhi peningkatan nilai $\mathrm{Y}$.

d. Berdasarkan tabel 4.25, diperolah hasil uji t untuk variabel Terpaan Media dengan melihat nilai t sebesar 5.031 dan signifikan ( sig. ) sebesar 0.000 . Artinya Sig. hitung $<0.05$ yaitu $0.000<0.05$. Dengan begitu menunjukan $\mathrm{Ha}$ diterima, bahwa variabel (X) secara individual memiliki pengaruh terhadap Opini (Y).

Dengan melihat hasil uji t hipotesis diantara variabel Terpaan Media (X) dan variabel Opini (Y) menunjukkan hasil yang cukup baik, yaitu Terpaan Media (X) dari Line Webtoon 'Wonderwall' memiliki pengaruh terhadap Opini (Y) pembacanya. 
Hal ini sesuai dengan Hipotesis (Ha) peneliti, yaitu terdapat pengaruh terpaan media Line Webtoon "Wonderwall" terhadap Opini Pembaca mengenai isu kesehatan mental. Artinya semakin tinggi tingkat frekuensi, durasi, dan atensi sebagai dimensi dari Terpaan media Line Webtoon "Wonderwall", maka semakin tinggi pengaruh terhadap opini pembaca.

Dalam penelitian ini, selama responden membaca Line Webtoon "Wonderwall" yang banyak menceritakan tentang tokoh utama jessy yang mengalami banyak masalah yang diakibatkan dari gangguan mental yang dialaminya, maka berdasarkan apa yang dibaca secara tidak langsung opini pembaca akan terpengaruh, sebagai contoh yang diambil dari pernyataan kuisioner yang telah disebar, 45 dari 100 responden sangat setuju dengan pernyataan bahwa setelah membaca Line Webtoon "Wondwerwall" responden merasa orang yang memiliki masalah kesehatan harus berkonsultasi dengan yang ahlinya atau 59 dari 100 responen setuju bahwa setelah membaca Line Webtoon "Wonderwall", responden merasa tidak memiliki masalah bila berdekatan atau berteman dengan seseorang yang memiliki masalah dengan kesehatan mental (depresi, stress, anxiety disorder, obsessive-compulsive disorder, dll). berdasarkan tabel distribusi frekuensi 4.15, juga ditermukan fakta bahwa dari total 100 responden ada 54 responden menjawab setuju dan 26 responden menjawab sangat setuju untuk pernyataan saat membaca Line Webtoon "Wonderwall", responden merasa bahwa masalah kesehatan mental (depresi, stress, anxiety Disorder, Obsessive-compulsive disorder, dll) yang diceritakan terlalu berlebihan.

Kemudian, berdasarkan hasil uji koefisien korelasi (R), pengaruh terpaan media terhadap opini termasuk kategori sedang dengan angka 0.457. Pada hasil koefisien determinasi ( $\mathrm{R}^{2}$ ), diketahui bahwa pengaruh Terpaan Media (X) terhadap Opini ( Y ) adalah sebesar 13,5\%, yang berarti 86,5\% lainnya merupakan faktor lain yang turut mempengaruhi namun tidak digunakan dalam penelitian ini. Dengan demikian, dapat disimpulkan bahwa faktor pembentuk Opini terdiri dari banyak faktor, sehingga dalam penelitian ini, yaitu menggunakan unsur Terpaan Media hanya berpengaruh $13,5 \%$.

Maka berdasarkan pembahasan di atas, dapat disimpulkan bahwa Line Webtoon "Wonderwall" sebagai sebagai salah satu konten dari media memiliki pengaruh terhadap pembaca sehingga beropini seperti, orang yang memiliki masalah dengan kesehatan mental harus berkonsultasi dengan yang ahli, menilai bahwa orang yang memiliki masalah dengan kesehatan mental harus mau menceritakan kepada teman/sahabat terdekatnya tentang masalah yang dialami, berharap lebih banyak orang yang perduli terhadap isu kesehatan mental, dan masih banyak opini lainnya yang dijabarkan di distribusi frekuensi.

\section{Simpulan}

Sesuai dengan hasil uji statistik dan analisis yang telah disajikan pada bab IV, maka dapat dikemukakan kesimpulan sebagai berikut:

1. Terdapat pengaruh dari terpaan media terhadap pembaca mengenai isu kesehatan mental, hal ini dapat dilihat dari hasil uji t yang menunjukan akan signifikan (sig.) 0.000 , yang artinya Ha diterima dan terdapat pengaruh terpaan media line webtoon wonderwall terhadap isu kesehatan mental.

2. Berdasarkan hasil uji koefisien korelasi terdapat hubungan antara terpaan media line webtoon "Wonderwall" dan opini pembaca mengenai isu kesehatan mental 
sebesar 0.457, yang artinya hubungan kedua variabel tersebut dapat dikategorikan sedang pada Table 3.3.

3. Dapat dilihat dari hasil uji koefisien determinasi, terdapat hasil sebersar 0,135. Yang artinya ada pengaruh terpaan media Line Webtoon "Wonderwall" sebesar 13,5\% terhadap Opini Pembaca mengenai isu kesehatan mental.

Berdasarkan penelitian ini, peneliti juga menemukan yaitu semankin tinggi frekuensi, durasi dan atensi Pembaca terhadap Line Webtoon "Wonderwall" maka semakin tinggi pula pengaruh terhadap opini pembaca mengenai isu kesehatan mental. Salah satu contoh bukti dari pernyataan yang diisi oleh responden adalah, pertanyaan nomor 12 dalam kuesioner. 50 dari 100 responden sangat setuju dengan pernyataan setelah membaca Line Webtoon "Wonderwall”, pembaca berpikir bahwa banyak orang yang mengalami masalah dengan kesehatan mental (depresi, stress, anxiety Disorder, Obsessive-compulsive disorder, dll) dan belum mendapatkan perhatian (tidak diperdulikan).

\section{Ucapan Terima Kasih}

Puji Syukur saya panjatkan kepada Tuhan Yang Maha Esa, karena telah melimpahkan berkat dan rahmat-Nya sehingga saya dapat menyelesaikan jurnal ini

Saya menyadari bahwa penyusunan jurnal ini tidak akan terwujud tanpa adanya bantuan dan dorongan dari berbagai pihak. Oleh karena itu pada kesempatan ini saya ingin menyampaikan ucapan terima kasih kepada yang terhormat :

1. Seluruh Dosen Fakultas Ilmu Komunikasi Universitas Tarumanagara yang telah memberikan bekal ilmu dan pengetahuan yang bermanfaat bagi saya.

2. Kepada keluarga yang selalu memberi dorongan, semangat, motivasi, serta selalu mendoakan saya dalam menyelesaikan tugas-tugas baik dari perkuliahan.

3. Serta kepada Meli, Vani, Dion, Nathania, Nevelyn, Widy, Helen, Revi, Ci Yola, Septian, Chel'en, Marlin, dan juga teman - teman penulis lainnya yang selalu memberikan dukungan baik dalam bentuk nasihat dan dorongan kepada penulis.

4. Para Responden atau Pembaca Line Webtoon 'Wonderwall' yang meluangkan waktu untuk mengisi kuisioner.

5. Semua pihak yang telah membantu terselesaikannya laporan skripsi ini yang tidak dapat saya sebutkan satu-persatu.

Semoga segala bimbingan dan bantuan yang telah diberikan kepada saya dapat saya gunakan dengan sebaik-baiknya oleh saya. saya menyadari bahwa masih banyak kekurangan dalam penyusunan jurnal ini baik dalam teknik penyajian materi maupun pembahasan. Oleh karena itu segala saran maupun kritikan yang bersifat membangun sangat diharapkan.

Akhir kata semoga jurnal ini dapat bermanfaat dan memberi inspirasi serta dapat menjadi referensi yang berarti bagi pihak yang membutuhkan.

\section{Daftar Pustaka}

Abdurrahman, Oemi. (1993). Dasar-dasar Public Relations. Bandung: Alumni. Ardianto, Elvinaro, dkk. (2014). Komunikasi Massa Suatu Pengantar. Bandung: Simbiosa Rekatama Media 
Putri, Destya Maya. (2018) Pengaruh Media Sosial Line Webtoon Terhadap Minat Membaca Komik Pada Mahasiwa Universitas Riau. Pekanbaru: JOM FISIP Vol. 5 No. 1

Rivers, William L., Clevemathews. (1994). Etika Media Massa dan Kecenderungan untuk melanggarnya. Jakarta: PT. Gramedia Pustaka Utama.

Rizki, Maharani Amelis. Pangestuti, Edriana. (2017) Pengaruh Terpaan Media Sosial Instagaram Citra Destinasi dan Dampaknya Pada Keputusan Berkunjung (Survei pada Pengunjung Kampung Warna Warni Jodipan, Kota Malang). Malang: Jurnal Administrasi Bisnis (JAB) Vol. 49 No.2

Sunarjo, Djoenaesih S. (1997). Opini Publik. Yogyakarta: Liberty Offse

Sugiyono. (2010). Metode Penelitian Pendidikan Pendekatan Kuantitatif, kualitatif, dan $R \& D$. Bandung: Alfabeta

Sugiyono. (2011). Metode Penelitian kuntitatif kualitatif dan R\&D. Jakarta: Alfabeta. Siregar, Syofian. (2015). Metode Penelitian Kuantitatif Dilengkapi Dengan Perbandingan Perhitungan Manual \& SPSS. Jakarta: Kencana

Sugianto, Karra. (2017). Opini Pemirsa Surabaya Terhadap Blur dalam Program Acara di Televisi. Surabaya: Jurnal E-Komunikasi, Universitas Kristen Petra Vol. 5 No.1

West, Richard. Turner, Lynn H. (2008) Pengantar Teori Komunikasi: Analisis dan Aplikasi (Buku 2) (Edisi 3), Jakarta: Salemba Humanika 